Available online at: https://proceeding.researchsynergypress.com/index.php/rsfconferenceseries1

RSF Conference Series: Business, Management and Social Sciences

e-ISSN 2807-5803/ p-ISSN 2807-6699

Volume 1 Number 3 (2021): 292-300

\title{
Importance-Performance Analysis: Evaluation E-Business Motivation Among SMEs in Indonesia
}

\author{
Titik Kusmantini' $^{1}$, Krisnandini Wahyu Pratiwi' ${ }^{1}$, Hendri Gusaptono' ${ }^{1}$, Darban Haryanto ${ }^{2}$ \\ ${ }^{1}$ Faculty of Economy and Business, UPN Veteran Yogyakarta, Indonesia \\ ${ }^{2}$ Faculty of Agriculture, UPN Veteran Yogyakarta, Indonesia
}

\begin{abstract}
This study aims to fill a research gap, namely exploring the extent to which small companies in Indonesia, especially batik SMEs in the Bantul district. The aim of the research is to understand the adoption of ebusiness applications. Evaluation of the extent to which the motivation of companies to adopt an ebusiness strategy is carried out using Importance-Performance Analysis (IPA). A total of 122 SMEs were obtained and sampled using the criteria of SMEs as family businesses and have implemented electronicbased business applications such as marketing blogs or Instagram or Facebook. The analysis technique used is not only based on the IPA framework but also using a sample data sorting technique with a Cartesian diagram to obtain what items of expectation have motivated SMEs to adopt e-business and how the performance achievements of these expectations have been achieved. This study identifies the priority items for SMEs in maximizing the use of e-commerce to support online sales, selection of potential supplier sources, and efforts to save promotional budgets.
\end{abstract}

Keywords: Importance-Performance Analysis; e-business motivation; a cartesian diagram

\section{INTRODUCTION}

Since the early 1990s, the rise of internet-based trading media has attracted a number of academics to observe the extent of opportunities for small companies to seize these opportunities. Is the adoption of internet technology able to increase the competitiveness of small companies with large scale companies (Robert, 2003; Schullo, 2004). Some researchers also identify that an e-business strategy will enable organizations to create business value in production, promotion, and recruitment activities. Hamill and Gregory (1997) mention that e-business practices for small companies are very effective in supporting companies to expand their market coverage. While Rayport and Sviokla (1995) emphasized the reasons for small companies adopting e-business to widely introduce the company and track customer preferences and tastes also make it easier for companies to change supply chain processes. Strauss et al. (2003) emphasized that a number of empirical evidence noted significant growth in small-scale companies adopting information technology or, in this case, the use of the internet to support their business management.

The empirical evidence of Strauss et al. (2003) is opposed by several other researchers, for example, Zank and Vokurka (2003), who notes that the growth of small companies is slower in adopting internet technology for managing their business, still dominated by medium and large scale companies, because researchers provide empirical evidence that large-scale companies earn more than small companies. This empirical evidence also supports the results of previous studies conducted by Haynes et al. (1998), Hart et al. (2000), and Jeffcote et al. (2012). Some of the reasons that can prevent small companies from being Corresponding author 
slow to adopt technology to manage an electronic-based business, namely because of limited financial and human resources capabilities. Evidence of the inaction of small companies was identified from a group of small companies that have not yet been adopted. Even further, a number of researchers mention cases of failure of small companies resulting in the company's reluctance to adopt electronic business. There are still many negative assessments from groups of companies that do not adopt e-based business. Most of them consider it a risk of investment decision.

For this reason, this study aims to investigate whether the reluctance to adopt an e-business is also faced by batik SMEs, even though in this decade, the growth of Indonesian batik market share is getting wider. Batik is increasingly widely known in various countries; of course, this requires e-business management skills. The formulation of the problem in this study is what is the priority scale for batik SMEs as small companies in the process of adopting e-business.

\section{LITERATURE REVIEW}

\section{E-business Motivation}

According to Levenburg, Magal, and Kosalge (2006), motivation in relation to e-business adoption decisions is defined as the perceived benefits that are anticipated and different from the benefits realized. The anticipated benefits reflect how strongly the company's motivation is to implement a particular ebusiness application in order to generate realizable benefits. Realized benefits may be the same or not the same as what the company's motivation was before adoption. Supposed a company can implement an application to facilitate online sales, this is done because they are motivated to increase sales. Then the real benefits that will be obtained later can vary, for example, reducing sales transaction cost, increasing customer satisfaction, or reducing delivery times.

Research that examines the motivation of small companies in the process of adopting e-business is still very minimal, and if there are three streams of literature categorized, firstly the motivations reported by a number of researchers to describe the readiness of small companies to engage in e-business; the second research focuses on testing the old concepts of the theoretical benefits of implementing e-business, and the third is only identifying a number of benefits obtained in the application of e-business. There is still a lack of research identifying the motivations of small firms to engage in e-business (Berrill et al., 2004; Levenburg et al., 2006). In this study, the measurement of motivation uses indicators of benefits which will generally be understood as something that can improve competitiveness and organizational performance.

\section{Importance-Performance Analysis.}

The lack of research that focuses on investigating how small companies understand the use of information technology has created research gaps. Given the search for academic literature, few studies have aimed to explore the extent to which small companies engaged in e-business practices believe this to be a prerequisite for achieving better performance. A number of researchers note the benefits that small companies get when implementing e-business practices. However, research that focuses on understanding the motivations and benefits expected by small companies for e-business adoption is still very rare.

According to Kuratko and Hodgets (2001), understanding e-business strategy in small companies is very important because the percentage of small companies represents the majority of businesses worldwide. So understanding the extent to which a small company's ability to select e-business applications is in accordance with their business strategy or not becomes something interesting and important to explore. This study is expected to be able to describe how far the maximum effort of small 
companies is in managing their scarce resources. For this reason, in the study later, the researcher uses an analytical framework for evaluating e-business motivation with IPA, and the measurement of the benefits obtained that can motivate companies to adopt e-business replicates the research instruments developed by previous studies by making adjustments according to the context of small companies in Indonesia.

Levenburg et al. (2006) explain the use of IPA as an analytical tool for (1) assessing e-business strategies based on the underlying motivation for their adoption (anticipated benefits); (2) make recommendations on resource allocation based on Importance - Performance Analysis. Actually, the benefits of this IPA are not only related to evaluating the effectiveness of strategies, but several previous researchers have also adopted many; for example, Skok et al. (2001) used IPA to measure the success rate of investment in information systems developed in the health industry, then O'Neil et al. (2001) also used IPA to evaluate service quality perceptions of online library service innovation. IPA itself was first developed by Martilla and James (1997) as a framework for understanding customer satisfaction as a function of both expectations related to salient attributes ("important") and assessments of their performance ("performance"). While each produces valuable information independently, it is potentially full of the type of information produced when the two are combined. So the first step should be to explore what attributes need to be considered and identify which are the top priority and which are the least priority.

As illustrated in Figure 1. regarding the IPA map as follows, while each produces valuable information independently. It is potentially full of the type of information produced when the two are combined. So the first step should be to explore what attributes need to be considered and identify which are the top priority and which are the least priority.

In our research, an important element in the adoption process is the importance of small firm motivation to engage in e-business practices. Subsequently, survey instruments were developed to collect importance and performance ratings on each element of the sample, often using a Likert or numerical scale (Skok et al., 2001). The literature related to considerations of importance and performance simultaneously follows two methodological streams, namely gap analysis and the IP map itself.

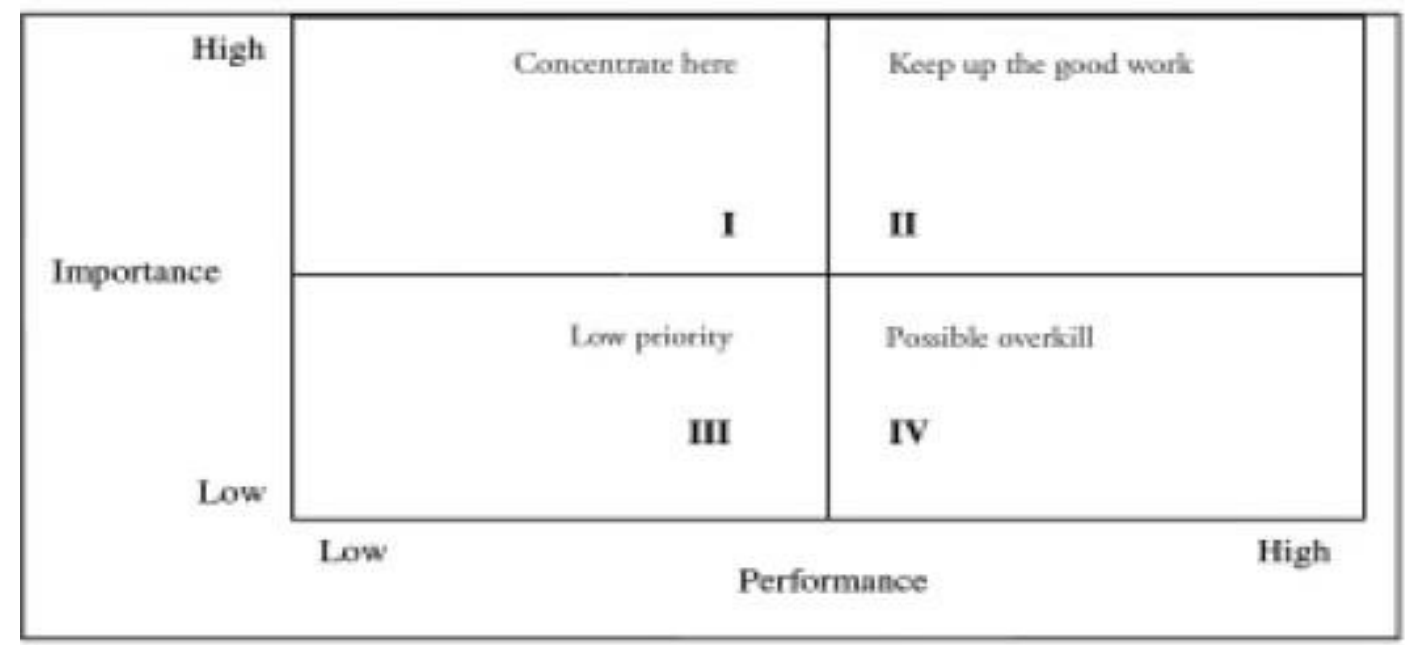

Figure 1: IPA Map Concept (Martilla and James, 1997)

Gap analysis focuses on identifying performance gaps, which are usually measured as performance minus importance (O'Neill et al., 2001; Skok etal., 2001; Shaw et al., 2002). Using gap analysis, O'Neill et al. 
(2001) identified underperformance (negative scores) on 16 of 18 attributes of online services offered by university libraries. Similarly, Shaw et al. (2002) apply gap analysis to measure the service quality of IS/IT systems. While Shaw et al. (2002) concluded that gap analysis is rigorously grounded and can be used appropriately in an IS context, others have criticized this method for theoretical shortcomings (Bacon, 2003). The second approach, the importance-performance (IP) map, involves plotting the average ratings for importance and performance on a two-dimensional grid to produce a four-quadrant matrix that identifies areas for improvement as well as areas that are effective.

\section{RESEARCH METHOD}

This study is based on survey data collected using a questionnaire designed to gain insight into ebusiness motivations and practices among small family-owned businesses. This sector of the economy was chosen because recent work has shown that small firms, dominated by family-owned businesses, are failing at a rapid rate (Upton et al., 2001a). For these companies, increasing competitiveness by implementing e-business practices may hold the key to improving business performance and increasing viability in the marketplace. The questionnaire was designed consisting of 19 items to measure motivation which refers to the research results of Levenburg et al. (2006). Respondents were asked to indicate, on a five-point Likert scale, namely measuring the level of importance of each item in motivating them to engage in e-business. In addition, they were asked to indicate, on another five-point Likert scale, how satisfied they were with the results. Demographic information is also collected (e.g., age of operation of the company, number of employees, annual income, market coverage).

\section{Discussion}

Bantul district is known as an area with industrial growth that is very developed; one of the industries that are growing significantly is natural batik dye. Several batik center villages such as Triharjo, Wukirsari, Trimulyo, and so on are known as the center of the written batik industry.

The batik products of SMEs in this region are well known in national and international markets, and efforts to increase sales growth are carried out by SMEs by adopting digital marketing practices. Using a sample of 122 batik SMEs in Bantul Regency, this study aims to evaluate the priority performance index expected by SMEs so that SMEs are motivated to adopt e-business. Table 1. presents 19 items of e-business motivation, which describe the level of satisfaction index of SMEs on the benefits of expectations and realizations obtained when they implement e-business. When the negative satisfaction index value reflects what is expected when e-business adoption has not been met, while if the satisfaction index value is positive, it reflects what the expectations can be realized, this means that the practice of e-business is able to provide benefits for the growth of the batik SME.

Table 1. SME Satisfaction Score Index e-business motivation

\begin{tabular}{|c|l|c|c|r|}
\hline \multirow{2}{*}{ Items } & \multirow{2}{*}{ Electronic business motivation items } & \multicolumn{2}{|c|}{ e-business motivation } & \multirow{2}{*}{ SCI } \\
& & Actual & expectancy & \\
& & 2.14 & 3.66 & 1.52 \\
\hline 2 & Building an SME business image & 3.32 & 3.74 & 0.42 \\
\hline 3 & Distributing SME productinformation & 3.52 & 2.42 & -1.1 \\
\hline 4 & Identify new customers Increase & 3.12 & 3.62 & 0.5 \\
\hline
\end{tabular}


RSF Conference Series: Business, Management and Social Sciences, Vol. 1 (3), 292-300

Importance-Performance Analysis: Evaluation E-Business Motivation Among SMEs in Indonesia Titik Kusmantini, Krisnandini Wahyu Pratiwi, Hendri Gusaptono, Darban Haryanto

\begin{tabular}{|c|l|c|c|r|}
\hline 5 & Creating a competitive advantage & 2.44 & 3.66 & 1.22 \\
\hline 6 & Build good communication with customers & 3.04 & 3.64 & 0.6 \\
\hline 7 & $\begin{array}{l}\text { Building good relationships with SMEbusiness } \\
\text { partners }\end{array}$ & 2.02 & 3.66 & 1.64 \\
\hline 8 & $\begin{array}{l}\text { Improve good communication with SME } \\
\text { employees }\end{array}$ & 2.04 & 3.88 & 1.84 \\
\hline 9 & $\begin{array}{l}\text { Helping SMEs to fulfill customer } \\
\text { requirements }\end{array}$ & 3.46 & 3.34 & -0.12 \\
\hline 10 & Creating online sales Improve & 3.64 & 2.02 & -1.62 \\
\hline 11 & marketing intelligence & 2.06 & 2.44 & 0.38 \\
\hline 12 & $\begin{array}{l}\text { Assist in the identification of new supply } \\
\text { sources. }\end{array}$ & 3.82 & 3.94 & 0.12 \\
\hline 13 & Helping SMEs to understandindustry data & 3.98 & 3.84 & -0.14 \\
\hline 14 & Able to reduce salesadministration costs & 3.96 & 3.62 & -0.34 \\
\hline 15 & $\begin{array}{l}\text { Able to reduce direct costs of theproduct } \\
\text { production process }\end{array}$ & 3.66 & 3.86 & 0.2 \\
\hline 16 & Reduce shipping costs Reduce & 3.92 & 3.82 & -0.1 \\
\hline 17 & budget for promotion Increase & 4.68 & 3.02 & -1.66 \\
\hline 18 & SME net profit Increase customer & 3.64 & 3.42 & -0.22 \\
\hline 19 & satisfaction Source: Primary data, & 2.32 & 3.26 & 0.94 \\
\hline
\end{tabular}

Given that there are still indicator items that have negative satisfaction scores, it is necessary to carry out further analysis using IPA. With the IPA matrix, we will have a picture of which items have a high realization of benefits and which are not yet optimal. To improve online business practices, SMEs are expected to prioritize online business motivation items in column I. Figure 2. is a Cartesian diagram and explains in column 1 there are items 10,12, and 17. It is important for batik SMEs to focus on maximizing the use of e-commerce for online support sales, selection of potential supplier sources, and efforts to save promotional budgets.

Column II reflects the extent to which the success of SMEs in achieving the realization of the benefits obtained when they apply online business practices. Performance achievements obtained due to the success of managing an online business include the ability to achieve benefits such as the ability to identify new customers, meet the requirements demanded by their customers, build competitive advantages, understand competitive conditions in the batik industry well and the ability to create good profits due to applying online business.

Meanwhile, in column III, explaining the benefit items that are less prioritized for batik SMEs is about the need to inform about product prices. Based on observations and interviews in the field, the price of batik products is very diverse because many things determine the price to be expensive. The type of motif, the application of the number of natural dyes used, and the level of refinement of the craftsmen in batik. 
In column IV, it explains the items that SMEs can do for future improvements in order to support their online business practices. Efforts to improve skills in order to build cooperation with trading partners, train employees, train salespeople and create an online service concept that is able to create customers. The concept of electronic service must be understood as a way to increase customer satisfaction; SMEs must understand the content of data and information that needs to be uploaded, continuously update data content and provide honest information for customers.

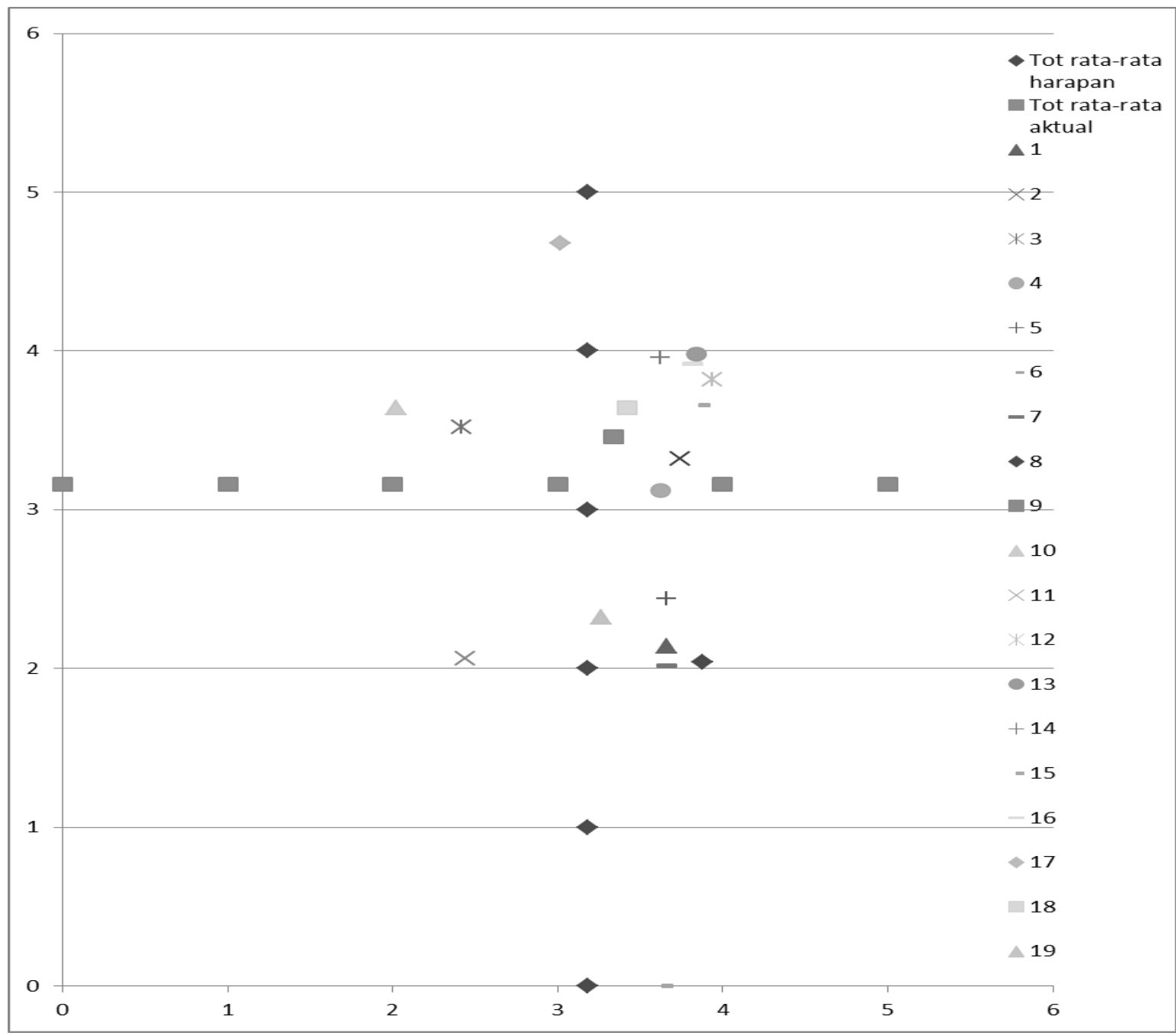

Figure 2. Cartesian diagram of e-business motivation

\section{CONCLUSION AND FUTURE RESEARCH}

The results of this study provide an understanding to the reader about what is the reason for batik SMEs in Bantul, especially in implementing online business practices. SMEs have expectations of the benefits that will be obtained when they adopt an online business. In order to support the success of SMEs in adopting e-business, it is necessary to train employees or SME owners to have skills in responding to transactions online sales quickly and efficiently, able to update data and information content, and able to sort out the correct information, so that customer reviews of SME online sales sites are positive. 


\section{ACKNOWLEDGMENTS}

The authors would like to thank the Institute for Research and Community Service at Universitas Pembangunan Nasional "Veterans" Yogyakarta, Indonesia, which has provided financial support for this research.

\section{REFERENCES}

Access Markets International (AMI) Partners, Inc. (2001) Analysis of the US Small Business Internet Environment, US Small Business Administration, Washington, DC, January .

Auger, P., Barnir, A., and Gallaugher, JM (2003). "Strategic Orientation, Competition, and InternetBased Electronic Commerce," Information Technology and Management (4:2-3), April-July, pp. 139-164. Auger, P., and Gallaugher, JM (1997). "Factors Affecting the Adoption of an Internet-Based Sales Presence for Small Businesses," The Information Society (13), pp. 55-74.

Bacon, DR (2003). "A Comparison of Approaches to Importance-Performance Analysis," International Journal of Market Research (45:1), pp. 55-71.

Barnes, D., Hinton, M., and Mieczkowska, S. (2003). "Competitive Advantage through e- Operations," Total Quality Management \& Business Excellence (14:6), August, pp. 659-675.

Barsky, BJ, and Labagh, R. (1992). "A Strategy for Customer Satisfaction," Cornell Hotel and Restaurant Administration Quarterly (33), pp. 32-39.

Barua, A., Konana, P., Whinston, A., and Yin, F. (2001). "Driving e-Business Excellence," MIT Sloan Management Review, Fall, pp. 36-44.

Burke, RR (2002). "Technology and the Customer Interface: What Consumers Want in the Physical and Virtual Stores," Academy of Marketing Science Journal (30:4), pp. 411-432.

Burns, AC, and Bush, RF (2003). Marketing Research, 4th ed., Prentice-Hall, Upper Saddle River, NJ, 2003.

Carlson, C. (2000). "Customer Service: An Essential Component for a Successful Web Site," Marketing Health Services (20:2), pp. 28-31.

Davies, AJ, and Garcia-Sierra, AJ. (1999). "Implementing Electronic Commerce in SMEs-Three Case Studies," BT Technology Journal (17:3), July, pp. 97-111.

Dolinsky, AL. (1994). "A Consumer Complaint Framework with Resulting Strategies: An Application to Higher Education," Journal of Services Marketing (8:3), pp. 27- 39.

Dolinsky, AL, and Caputo, RK. (1991). "Adding a Competitive Dimension to ImportancePerformance Analysis: An Application to Traditional Health Care Systems," Health Marketing Quarterly (8:3/4), pp. 61-79.

Donckels, R., and Frohlich, E. (1991). "Are Family Businesses Really Different? European

Experiences from STRATOS," Family Business Review (5:1), pp. 149-160.

Duke, CR, and Mount, AS. (1996). "Rediscovering Performance-Importance Analysis of Products," The Journal of Product and Brand Management (5:2), pp. 43-54.

Geiger, S., and Martin, S. (1999). "The Internet as a Relationship Marketing Tool-Some Evidence from Irish Companies," Irish Marketing Review (12:2), pp. 24-37.

Graf, LA, Hemmasi, M., and Nielsen, W. (1992). "Importance-Satisfaction Analysis: A Diagnostic Tools for Organizational Change," Leadership and Organization Development Journal (13:6), pp. 8-12.

Grandon, EE, and Pearson, JM. (2004). "Electronic Commerce Adoption: An Empirical Study of Small and Medium US Businesses," Information \& Management (42), pp. 197- 216. 
Griffith, DA, and Krampf, RF. (1998). "An Examination of the Web-Based Strategies of the Top 100 US Retailers," Journal of Marketing Theory and Practice (6:3), Summer, pp. 12-23.

Grossman, M. (2004). "The Role of Trust and Collaboration in the Internet-Enabled Supply Chain," The Journal of the American Academy of Business, September, pp. 391-396.

Gudmundson, D., Hartman, EA, and Tower, CB. (1999). "Strategic Orientation: Differences between Family and Nonfamily Firms," Family Business Review (12:1), March, pp. 27-39.

Hadjimanolis, A. (2000). "A Resource-Based View of Innovativeness in Small Firms," Technology Analysis and Strategic Management (12:2), pp. 263-281.

Hamill, J., and Gregory, K. (1997). "Internet Marketing in the Internationalization of Adopters and Non-Adopters of WWW," Journal of Marketing Management (13:1-3), pp. 9- 28.

Hart, K., Doherty, N., and Ellis-Chadwick, F. (2000) "Retailer Adoption of the Internet," European Journal of Marketing (34:8), pp. 954-974.

Haynes, PJ, Becherer, RC, and Helms, MM. (1998). "Small and Mid-Sized Businesses and Internet Use: Unrealized Potential?" Internet Research (8:3), pp. 229-235.

Kolesar, MB, and Galbraith, RW. (2000). "A Services-Marketing Perspective on e-Retailing: Implications for e-Retailers and Directions for Further Research," Internet Research (10:5), pp. 424-438.

Kuratko, DF, and Hodgetts, RM. (2001). Entrepreneurship: A Contemporary Approach, 5th ed., Harcourt College Publishers, Fort Worth, TX.

Lederer, AL, Mirchandani, DA, and Sims, K. (2001). "The Search for Strategic Advantage on the Web," International Journal of Electronic Commerce (5:4), pp. 117-133.

Levenburg, NM, and Dandridge, TC (2000). "High Tech. Potential?: An Exploratory Study of Small Firms and Usage of the Internet," International Small Business Journal (18:2), pp. 81-91.

Levenburg, NM, Schwarz, TV, and Dandridge, TC (2002). "Understanding Adoption of Internet Technologies," in Proceedings of the 16th Annual USASBE National Conference, January 17-20, CD-ROM.

Martilla, JA, and James, JC (1997). "Importance-Performance Analysis," Journal of Marketing (41:1), pp. 77-79.

O'Neill, M., Wright, C., and Fitz, F. (2001) "Quality Evaluation in On-Line Service Environments: An Application of the Importance-Performance Measurement Technique," Managing Service Quality (11:6), pp. 402-417.

Pflughoeft, KA, Ramamurthy, K., Soofi, ES, Yasai-Ardekani, M., and Zahedi, F. (2003). "Multiple Conceptualizations of Small Business Web Use and Benefit," Decision Sciences (34:3), pp. 467-512.

Poon, S., and Swatman, PMC (1999). "An Exploratory Study of Small Business Internet Commerce Issues," Information and Management (35:1),pp. 9-18.

Rayport, JF, and Sviokla, JJ (1995). "Exploring the Virtual Value Chain," Harvard Business Reviews (73:6), pp. 75-85.

Shaw, NC, DeLone, WH, and Niederman, F.(2002). "Sources of Dissatisfaction in End-User Support: An Empirical Study," Database for Advances in Information Systems (33:2), Spring, pp. 41-56.

Skok, W., Kophamel, A., and Richardson, I. (2001). "Diagnosing Information Systems Success: Importance- Performance Maps in the Health Club Industry," Information \& Management (38), pp. 409-

Slack, N. (1994). "The Importance-Performance Matrix as a Determinant of Improvement Priority," International Journal of Operations \& Production Management (14:5), pp. 59- 76 
Strauss, J., El-Ansary, A., and Frost, R.(2003). e-Marketing, 3rd ed., Prentice Hall, Upper Saddle Rivers, NJ.

Upton, N., McLeod, H., and Oh, KY (2001). "Managing Family Firms in Small Communities," Journal of Small Business Management (39:1), pp. 73-87.

Upton, N., Teal, EJ, and Felan, JT (2001). "Strategic and Business Planning Practices of Fast Growth Family Firms," Journal of Small Business Management (39:1), pp. 60- 72.

Ward, JL (1997). "Growing the Family Business: Special Challenges and Best Practices," Family Business Review (10:4), December, pp. 323-337.

Zeithaml, VA (2002). "Service Excellence in Electronic Channels," Managing Service Quality (12:3), pp. 135-138.

Zhuang, Y., and Lederer, AL (2003). "An Instrument for Measuring the Business Benefits of eCommerce Retailing," International Journal of Electronic Commerce (7:3), Spring , pp. 65-99. 